\title{
FUNGICIDAL EFFEGTS OF SOME CHEMICALS ON SCLEROTINIA TRIFOLIORUM ERIKSS.
}

\author{
AARRE YLIMÄKI
}

Received August 20, 1969.

\author{
Department of Plant Pathology, Agricultural Research Centre, Tikkurila, Finland
}

In field trials carried out by the Department of Plant Pathology it has been established that clover rot (Sclerotinia trifoliorum Erikss.) can effectively be controlled by PCNB (quintozene-)-preparations (YLIMÄKI 1955, 1956, 1969). The effect of these fungicides and their dependence on environmental factors as well as the effectiveness of some other chemicals on $S$. trifoliorum has been studied.

\section{Methods}

Since the effect of fungicides on the growth of mycelium in $S$. trifoliorum is easier to study, and as fumigation of fungicides appears to be a relatively advantageous, the studies were carried out as plate tests. The chemicals were placed in weighed amounts on four filter papers of $10 \mathrm{~mm}$. These were placed on the surface of agar from where at least the watersoluble chemicals could diffuse along the agar surface. The fungus was transferred into the middle of the plate (c.f. Fig. 1). In some cases the fungicides were dusted or sprayed direct on the mycelium which had already started to grow.

To establish merely the fumigation effect of the chemicals, the substance under study was placed in a small plastic cup inside the cover of the Petri dish, upside down and with the fungus on the medium above it.

The growth of the mycelia was measured daily and observations were made on the formation of sclerotia. Microscopical studies were made to see whether the chemicals had caused visible changes in the mycelia. From the treated dishes the mycelia and sclerotia were transferred again on the normal medium so as to established whether the treatment had caused permanent changes in the mycelia. For a study of the sporophores the sclerotia were germinated on water agar or on wet quartz sand.

\section{Results}

The experiments (Table 1, Figs. 1-4) showed that the chemicals had a relatively restraining effect on the mycelium of $S$. trifoliorum, but as many of these substances are 
Table 1. Effect of various chemicals on Sclerotinia trifoliorum in laboratory trials.

\begin{tabular}{|c|c|c|c|c|}
\hline \multirow[t]{2}{*}{ Preparation } & \multirow[t]{2}{*}{ Active ingredients } & \multicolumn{3}{|c|}{$\begin{array}{l}\text { Mycelial growth mm } \\
\text { after days }\end{array}$} \\
\hline & & 2 & 6 & 12 \\
\hline
\end{tabular}

Mercuric compounds

Agrosan GN

Atiran

Ceresan Nb.

CRC

Duphar mercury spray

Femma

Germisan

Mercadmine

Solusan

Täyssato

Verdasan

YF 5049

Amatin Staub

Avicol dust

Avicol wp.

Botrilex

Brassicol dust

Brassicol sup.

Fartox dust

Folosan

Olpisan

Bulbosan

Bulbosit

Dithane Z-78

Duphar ferbam

Orthocide 75

Orthocide 50

Kuprijauhe

KT 35 phenylmercury acetate $0.85 \%+$ ethylmercury chloride $0.15 \%$

methoxyethylmercury chloride $4.6 \%$

methoxymercury acetate $2.4 \%$

mercurochloride $4 \%$

phenylmercury cellulose ether $4.3 \%$

phenylmercury acetate $2.0 \%$

phenylmercury pyrocatechine $3.3 \%$

phenylmercury salicylate $5 \%$

methylethylmercury acetate $(\mathrm{Hg} 15,0 \%)$

methoxyethylmercury chloride $2.2 \%$

phenylmercury acetate $5 \%$

phenylmercury salicylate anilide $96 \mathrm{~g} / \mathrm{l}$

Average

$\begin{array}{rcc}9.5 & 28.4 & 33.7 \\ 16.3 & 29.9 & 44.9 \\ 16.3 & 26.3 & 31.4 \\ 9.5 & 59.0 & 100 \\ 11.1 & 29.5 & 35.3 \\ 10.5 & 43.2 & 51.6 \\ 9.5 & 33.7 & 40.0 \\ 4.8 & 23.2 & 25.3 \\ 7.4 & 18.9 & 20.0 \\ 7.9 & 29.5 & 66.8 \\ 11.6 & 29.3 & 31.0 \\ 5.3 & 15.8 & 15.8 \\ 10.0 & 30.6 & 41.3\end{array}$

\section{Benzenes}

hexachlorobenzene (HCB) $20 \%$

quintozene (PCNB) $20 \%$

$\begin{array}{crr}12.1 & 61.1 & 97.4 \\ 0 & 9.4 & 31.8 \\ 4.8 & 13.2 & 26.1 \\ 4.6 & 20.3 & 53.1 \\ 7.5 & 18.9 & 44.5 \\ 6.0 & 20.2 & 38.8 \\ 9.4 & 22.4 & 24.1 \\ 1.2 & 5.1 & 11.7 \\ 4.2 & 15.4 & 39.6 \\ 5.3 & 12.6 & 26.8 \\ 10.0 & 47.4 & 73.7 \\ 5.2 & 40.1 & 38.0\end{array}$

Thiocarbamates

zineb $65 \%$

ferbam $95 \%$

$\begin{array}{lll}12.6 & 63.2 & 92.1\end{array}$

$13.7 \quad 38.2 \quad 52.1$

$\begin{array}{llll}\text { Average } & 13.2 & 50.7 & 72.1\end{array}$

Captan compounds

captan $75 \%$

captan $50 \%$

$\begin{array}{lll}16.3 & 63.7 & 89.0\end{array}$

$\begin{array}{lll}0 & 57.0 & 76.3\end{array}$

$\begin{array}{llll}\text { Average } & 8.2 & 60.4 & 82.7\end{array}$

Copper compounds

copper oxychloride $85 \%$

$$
\text { " } 60 \%
$$

18.9

$87.5 \quad 100$

$\begin{array}{lll}27.1 & 70.6 & 70.6\end{array}$

$\begin{array}{llll}\text { Average } & 23.0 & 79.1 & 85.3\end{array}$ 
Preparation
Mycelial growth $\mathrm{mm}$ after days

6 12

\section{Antibiotics}

\begin{tabular}{|c|c|c|c|c|}
\hline Actidione & cycloheximide $85-100 \%$ & 15.3 & 22.0 & 22.8 \\
\hline Agrimycin & streptomycin $15 \%$ + oxytetracycline $1.5 \%$ & 27.1 & 100 & 100 \\
\hline Griseofulvin & griseofulvin $98 \%$ & 22.6 & 76.3 & 88.4 \\
\hline Kojic acid & 5-hydroxy-2 hydroxine-ethyl-4 pyrone & 30.7 & 100 & 100 \\
\hline Sorbistat & sorbic acid & 26.7 & 70.8 & 84.7 \\
\hline Usno & usnic acid & 29.2 & 98.8 & 96.5 \\
\hline U-4527 & cycloheximide & 19.4 & 25.9 & 26.8 \\
\hline U-7413 & , $\quad$-oxime & 25.2 & 75.9 & 81.6 \\
\hline U-7414 & -acetate & 27.6 & 97.5 & 98.7 \\
\hline \multirow[t]{2}{*}{ U-7415 } & -semicarbazone & 25.7 & 85.1 & 86.8 \\
\hline & Average & 25.0 & 75.2 & 78.6 \\
\hline
\end{tabular}

Pomarsol forte

Fusarex plus

KT 6

VP $19-40=$ Brestan Bayer 4934

Riedel B/500

Tuset

Spergon

Phygon

Belvitan K

Controls
Other compounds

thiram $80 \%$

tecnazene $2 \%+$ isopropyl N-phenylcarbamate (IPC) $1 \%$

quintozene (PCNB) $5 \%+$ isopropyl N-phenylcarbamate (IPC) $1 \%$

triphenyl stannic acetate $20 \%$

urbasulf $32 \%$ (As $20 \%$ )

oxychinolin halogen deriv. $1.0 \%$

thiram $40 \%+$ zineb $20 \%$

chloranil $96 \%$

dichlone $50 \%$

methyl $\alpha$-naphtylmethylether (MNME) $4 \%$ $\begin{array}{lll}0 & 11.6 & 21.1\end{array}$

$\begin{array}{lll}7.4 & 35.3 & 52.5\end{array}$

$\begin{array}{lll}9.2 & 36.1 & 56.3\end{array}$

$11.2 \quad 21.8 \quad 23.5$

$\begin{array}{lll}2.7 & 44.8 & 100\end{array}$

$\begin{array}{lll}11.6 & 31.6 & 91.1\end{array}$

$\begin{array}{lll}0 & 41.1 & 72.6\end{array}$

$\begin{array}{lll}0 & 14.7 & 57.9\end{array}$

$\begin{array}{lll}- & - & - \\ 14.3 & 68.8 & 92.6\end{array}$

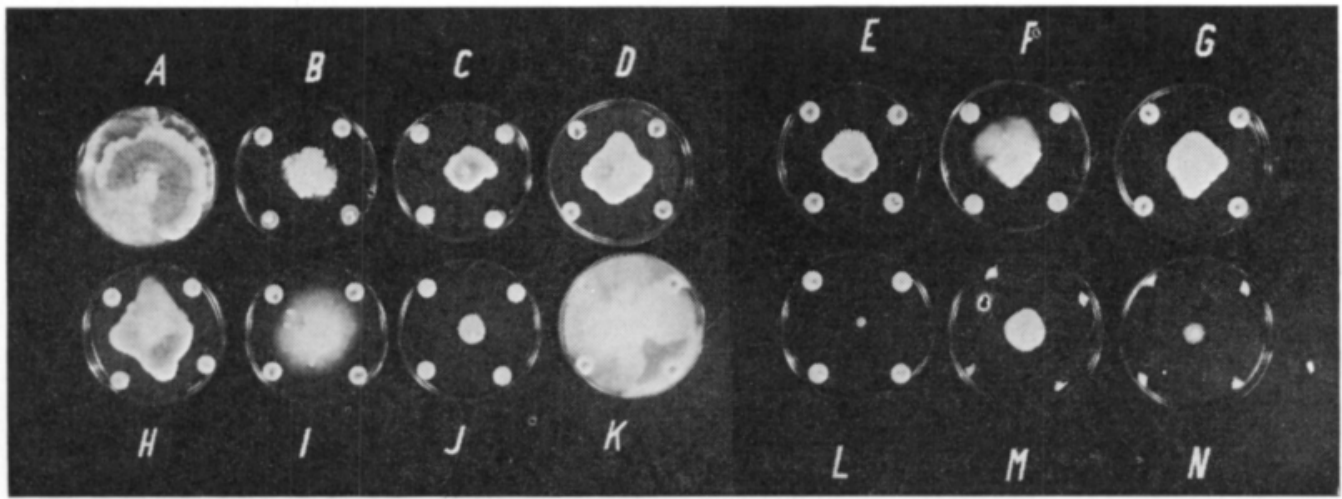

Fig. 1. Effect of various fungicides on the growth of Sclerotinia trifoliorum mycelium. A. control, B. Brassicol super wp., C. Verdasan, D. Germisan, E. Täyssato, F. Solusan, G. CRC, H. Agrosan GN, I. Atiran, J. Duphar mercury spray, K. Femma, L. Granosan, M. Mercadmine, N. YF 5049. 


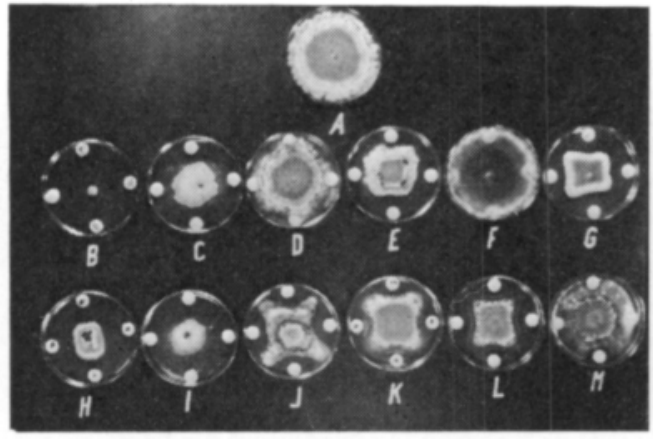

Fig. 2. Effect of various fungicides on the growth of Sclerotinia trifoliorum mycelium. A. control, B. Folosan, C. Brassicol, D. Dithane Z-78, E. Atiran, F. Kuprijauhe, G. Verdasan, H. Ceresan Nb., I. Brassicol wp., J. Brestan, K. Duphar ferbam, L. Pomarsol forte, M. Orthocide 75.

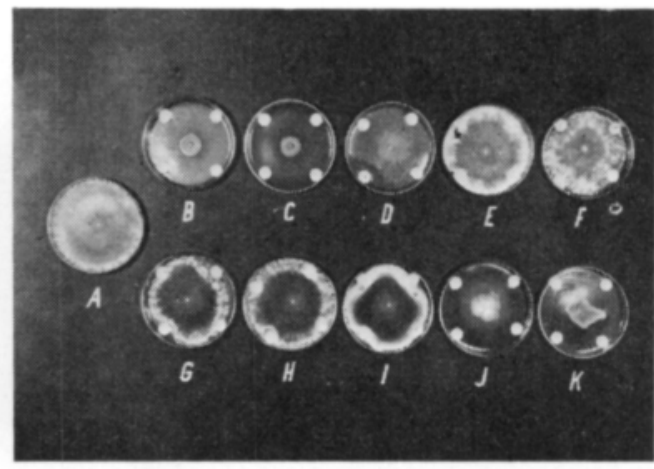

Fig. 3. Effect of various antibiotics on the growth of Sclerotinia trifoliorum mycelium. A. control, B. Actidione, C. U-4527, D. U-7413, E. U-7414, F. U-7415, G. Griseofulvin, H. Usno, I. Sorbistat, J. Brassicol wp., K. Verdasan.

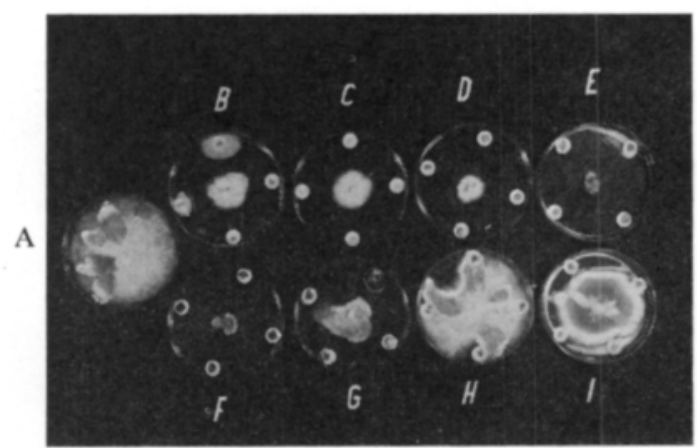

Fig. 4. Effect of various benzene-preparations on the growth of $S$. trifoliorum mycelium. A. control, B. Brassicol wp. C. Olpisan, D. Bulbosan, E. Folosan, F. Fusarex plus, G. KT 6, H. Amatin Staub, I. Bulbosit.

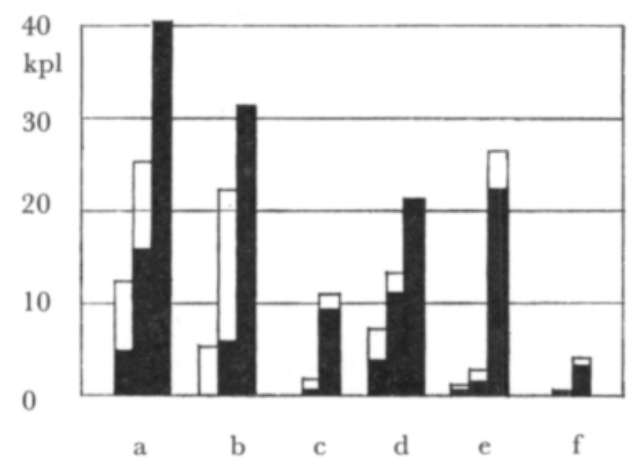

Fig. 6. The same trial as in Fig. 5. Number of sclerotia 10, 20, 39 days after inoculation.

$\square$ light sclerotia black sclerotia
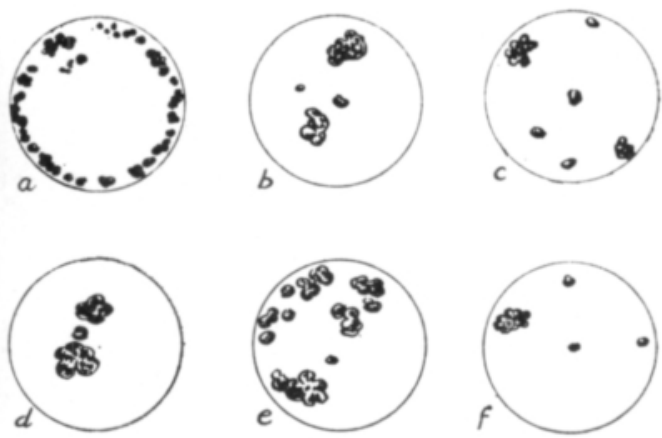

Fig. 5. Effect of fungicides on the formation of sclerotia in petri dishes. a. control, b. MNME, c. PCNB, d. zineb, e. captan, f. TCNB.
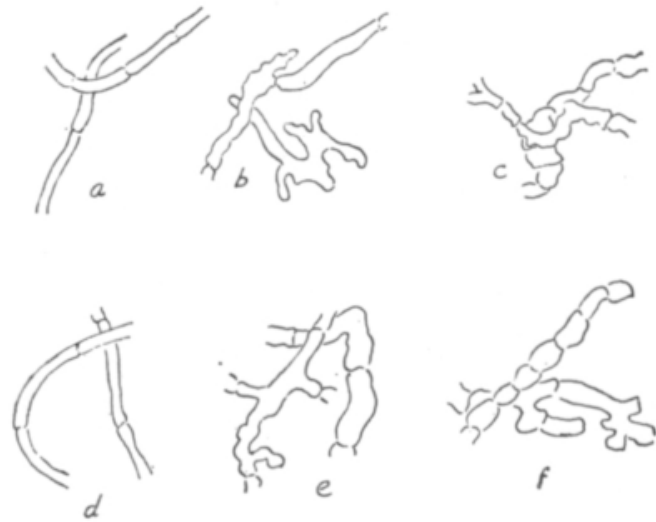

Fig. 7. Effect of some fungicides on the growth of mycelia of $S$. trifoliorum. a. control, b. MNME, c. PCNB, d. zineb, e. captan, f. TCNB. 

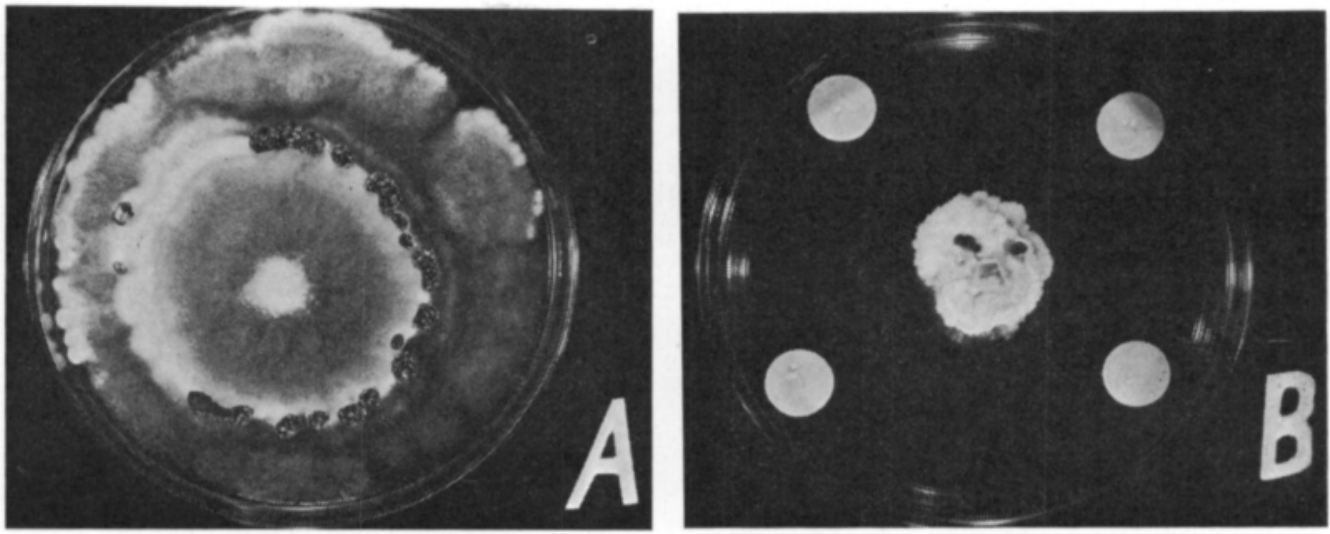

Fig. 8. Effect of PCNB preparations on the growth of mycelia and formation of sclerotia of $S$. trifoliorum. A. control, B. Avicol wp.

Table 2. The preservation of the efficacy of TCNB and PCNB preparations in open dishes.

\begin{tabular}{cccc}
\hline Preparation & $\begin{array}{c}\text { Duration } \\
\text { of trial }\end{array}$ & $\begin{array}{c}\text { Growth of mycelium } \\
\mathrm{mm}\end{array}$ & rel. \\
\hline
\end{tabular}

\begin{tabular}{lcccr}
\multicolumn{5}{c}{ A. At room temperature } \\
Folosan & TCNB & 10 days & 9.0 & 10 \\
Brassicol & PCNB &, & 36.3 & 38 \\
Control & &, & 95.0 & 100 \\
L.S.D. & & & $4.7 * * *$ & \\
& & & & \\
Folosan & TCNB & 10 months & 45.8 & 48 \\
Brassicol & PCNB &, & 86.3 & 90 \\
Control & &, & 95.0 & 100 \\
L.S.D. & & & $14.4 * * *$ &
\end{tabular}

\begin{tabular}{lcclr}
\multicolumn{5}{c}{ B. Out of doors } \\
Folosan & TCNB & 16 days & 15.2 & 17 \\
Avicol & PCNB &, & 76.4 & 85 \\
Control & &, & 90.0 & 100 \\
L.S.D. & & & $6.8 * * *$ &
\end{tabular}

poisonous it is not possible to use them on grasslands. Moreover, the substances whi chin laboratory trials were rather effective, have proved to be less effective in field trials than the PCNB substances, which in field trials have effectively controlled the damage of clover rot (YLIMÄKI 1969).

When TCNB, PCNB, or captan preparations, were sprinkled on the mycelia transferred to the medium the growth of the mycelia of $S$. trifoliorum and the formation of sclerotia were seriously disturbed. TCNB was more effective in preventing the growth of mycelia than PCNB (Fig. 4), whereas the preventive effect on the formation of sclerotia was very similar in both (Figs. 5 and 6 ). 
Table 3. Preservation of TCNB and PCNB preparations in different conditions

\begin{tabular}{ll}
\hline Way of storage & \\
\hline In a room, closed dish & Trial I
\end{tabular}

In a room, closed dish
,
,
,

In a room, open dish, dry

,

,

",

In a room, open dish, wet ,

Out of doors, open dish, wet

,

,

Control

L.S.D.

Trial II

In a room, closed dish

",

In a room, open dish

In a cool place, open dish

\section{Control}

$$
\text { L.S.D. }
$$

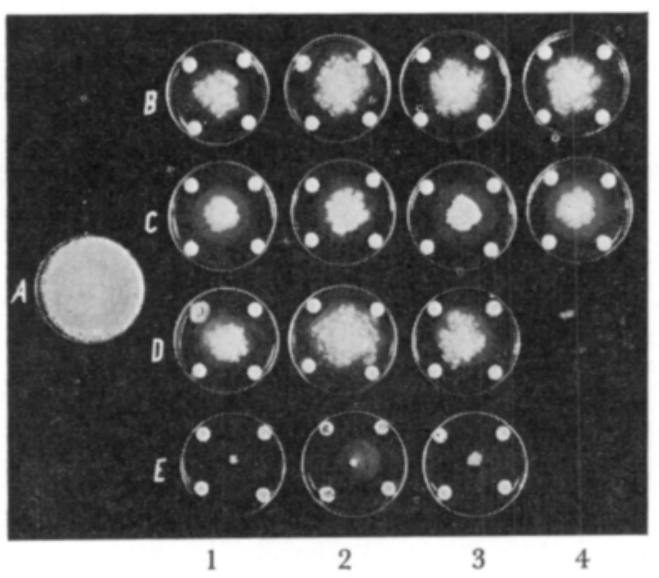

Growth of mycelium $\mathrm{mm}$ rel.
Brassicol sup.

Brassicol dust

Avicol wp.

Folosan

Brassicol sup.

Brassicol dust

Avicol wp.

Folosan

Brassicol sup.

Avicol wp.

Brassicol sup.

Brassicol dust

Avicol wp.

Folosan, an old amount

Folosan, an new amount

Botrilex, an old amount

Botrilex, an new amount

Folosan

Botrilex

Folosan

Botrilex
Folosan

$\begin{array}{crr}\text { PCNB } & 32.5 & 34 \\ ,, & 44.5 & 47 \\ ,, & 23.5 & 25 \\ \text { TCNB } & 7.0 & 7 \\ \text { PCNB } & 39.0 & 41 \\ ,, & 43.5 & 46 \\ ,, & 25.5 & 27 \\ \text { TCNB } & 8.5 & 9 \\ \text { PCNB } & 31.5 & 33 \\ ,, & 44.5 & 47 \\ \text { PCNB } & 45.0 & 47 \\ ,, & 51.0 & 54 \\ , \% & 26.5 & 28 \\ \text { TCNB } & 12.5 & 13 \\ & 95.0 & 100\end{array}$

$\begin{array}{clr}\text { TCNB } & 12.5 & 14 \\ ,, & 18.0 & 20 \\ \text { PCNB } & 57.5 & 63 \\ ,, & 69.3 & 76 \\ \text { TCNB } & 41.0 & 45 \\ \text { PCNB } & 79.5 & 88 \\ \text { TCNB } & 19.8 & 22 \\ \text { PCNB } & 32.3 & 36 \\ & 90.7 & 100 \\ & 12.6^{* * *} & \end{array}$

Fig. 9. Evaporation trial with benzene preparations. A. control, B. Brassicol wp., C. Avicol wp., D. Brassicol dust, E. Folosan; storage 1. in closed parcel 2. in open dish out of doors, wet 3. in open dish in a room, dry 4 . open dish in a room, wet. 
Table 4. Effect of temperature on the preservation of PCNB preparations. Substances preserved in open dishes during one month.

\begin{tabular}{|c|c|c|c|c|}
\hline \multirow{3}{*}{ Preparation } & \multicolumn{4}{|c|}{$\begin{array}{c}\text { Growth of mycelium } \\
\text { Temperature }\end{array}$} \\
\hline & \multicolumn{2}{|c|}{$\left(15-37^{\circ} \mathrm{C}\right)$} & \multicolumn{2}{|c|}{$\left(4-18^{\circ} \mathrm{C}\right)$} \\
\hline & $\mathrm{mm}$ & rel. & $\mathrm{mm}$ & rel. \\
\hline Brassicol super wp. & 31.0 & 41 & 24.0 & 32 \\
\hline Avicol wp. & 23.5 & 31 & 27.0 & 36 \\
\hline Avicol dust & 24.0 & 32 & 24.0 & 32 \\
\hline Botrilex dust & 26.5 & 35 & 25.0 & 33 \\
\hline Brassicol dust & 25.0 & 33 & 25.0 & 33 \\
\hline Control & 75.0 & 100 & - & - \\
\hline L.S.D. & & & $9.0^{*}$ & \\
\hline
\end{tabular}

Observed microscopically, the mycelia which had interrupted their growth, seemed alive, even if abnormally thick and crooked (Fig. 7). The formation of appressors was more abundant in dishes treated with fungicides than in untreated dishes. The sclerotia formed more rapidly in control dishes. They were mainly on the edges of the dishes, whereas in the dishes treated with chemicals their occurrence was haphazard and they appeared mostly in groups joined to each other (Fig. 5). When transferred to an untreated medium, the abnormal mycelia and sclerotia were able again to form mycelia and sclerotia that seemed to be totally healthy.

The sclerotia from the mycelia treated with TCNB as well as with PCNB preparations formed numerous sporophores, they developed no apothecia, however, whereas in untreated sclerotia they developed normally.

Although pieces taken from the mycelia treated with both substances and placed on nonpoisonous medium formed normal kind of mycelium and sclerotia, these sclerotia did not develop normal sporophores as did the sclerotia of the control. It seems possible that TCNB and PCNB substances may have effects of more lasting nature on the $S$. trifoliorum fungus,

Preventing the growth of the mycelia of $S$. trifoliorum and the formation of sclerotia is clearly a fungistatic process (cf. STRECKer 1957). The activity of these substances is dependent on the temperature: in the same temperature TCNB is more fungistatic than PCNB. Since the vapor pressure of the TCNB is $4-5$ times greater in the same temperature as the vapor pressure of PCNB (REAvill 1954), the difference in the efficacy of the substances may depend mainly on the difference in fumigation. In all trials where the TCNB preparation was used, it was more effective on $S$. trifoliorum than the PCNB preparations (Tables 2 - 3, Figs. 2, 4 and 9).

As the preventive treatments in the control of clover rot should be started rather early (YLIMÄKI 1969), it is important to know how long the fungicide remains effective in field conditions. The length of the time the substances preserve their effectiveness in storage should also be known. To study these qualities, the TCNB and PCNB preparations were kept in different temperature and humidity conditions.

In the trials the effect of the temperature, the humidity and the air current on the effectiveness of TCNB and PCNB was so small that the above factors cannot have a 
perceptibly lowering effect on the usability of TCNB or PCNB on the fields in autumn conditions (Table 4). In fact, the substances may loose their effectiveness when stored at higher temperatures in open or badly closed covers. In the trials this applied in particular to the PCNB preparations (Tables 2 and 3 ).

\section{Su m m a ry}

In efficiency tests carried out in laboratory (Table 1, Figs. 1-4) it was established that on media many chemicals had a restraining effect on the growth of the mycelia of Sclerotinia trifoliorum. In addition to PCNB preparations, TCNB substances very severely restrained the growth of mycelia and the formation of sclerotia of the fungus (Figs. 5-8). Sclerotia formed of mycelia treated with TCNB as well as with PCNB substances developed numerous sporophores which were not fertile however. The effect of both PCNB and TCNB on the mycelium of $S$. trifoliorum proved only restricting on the growth. It did not destroy the mycelia. The activity of the substances is dependent on the temperature and the higher effectivity of TCNB is based on its greater degree of vaporization (Tables 2-3, Figs. 2,4 and 9). In autumn and in outdoor conditions on the field the vaporization of the substances is so small that it does not lower the effectiveness to any great extent (Tables 2-3, Fig. 9).

\section{REFERENCES}

Reavill, M. 1954. Effect of certain chloronitrobenzenes on germination, growth and sporulation of some fungi. Ann. Appl. Biol. 41: 448-460.

Strecker, B. 1957. Untersuchungen über die Einwirkung von organischen Fungiziden auf Bodenpilze. Z. Pfl.krankh. (Pfl.path.) und Pfl.schutz 64: 9-35.

YцiмÄкI, A. 1955. On the effectiveness of penta- and tetrachloronitrobenzenes on clover rot (Sclerotinia trifoliorum Erikss.) Acta Agr. Fenn. 83: 147-158.

——- 1956. Additional experiments on the chemical control of clover rot. Selostus: Lisäkokemuksia apilamädän torjumisesta kemiallisilla aineilla. Valt. Maatal.koetoim. Julk. 148: 31—49.

—— 1969. Apilamätä apilan talvehtimisen heikentäjänä Suomessa. Summary: Clover rot as a cause of poor overwintering of clover in Finland. J. Sci. Agric. Soc. Finl. 41:

\section{SELOSTUS}

ERÄIDEN KEMIKAALIEN VAIKUTUS SCLEROTINIA TRIFOLIORUM SIENEEN

AARre YlimÄKI

Kasvitautien tutkimuslaitos, Maatalouden tutkimuskeskus, Tikkurila

Laboratoriossa suoritetuissa tehokokeissa (taulukko 1, kuvat 1-4) ilmeni, että monilla kemikaaleilla oli ravintoalustoilla $S$. trifoliorum'in rihmaston kasvua ehkäisevä vaikutus, mutta useat niistä eivät kuitenkaan ole käyttökelpoisia nurmilla myrkyllisyytensä takia. PCNB-valmisteiden ohella myös TCNB-aineella oli erittäin voimakas sienen rihmaston kasvua ja rihmastopahkojen muodostumista ehkäisevä vaikutus (kuvat 5-8). Sekä TCNB- että PCNB- aineilla käsitellyistä rihmastoista muodostuneet rihmastopahkat kehittivät lukuisia itiöemien aiheita, jotka kuitenkaan eivät olleet fertiilejä.

Sekä PCNB:n että TCNB:n vaikutus $S$. trifoliorum'in rihmastoon oli vain kasvua ehkäisevä, ei tappava. Aineiden aktiivisuus on riippuvainen lämpötilasta ja perustuu TCNB:n suurempi tehokkuus sen suurempaan kaasuuntuvuuteen (taulukot $2-5$, kuvat 2, 4, 9). Syksyisin ulkona pellolla vallitsevissa sääoloissa on aineiden kaasuuntuvuus kuitenkin siksi vähäinen, ettei sillä ole mainittavasti tehoa heikentävää vaikutusta (taulukot 2-5, kuva 9). 